\title{
EFEK EKSTRAK ETANOL DAUN KEMANGI (Ocimum sanctum L.) SEBAGAI AGEN KEMOPREVENTIF PADA SEL KANKER LEHER RAHIM HELA MELALUI AKTIVITAS SITOTOKSIK DAN INDUKSI APOPTOSIS
}

\author{
THE EFFECT OF Ocimum sanctum L. LEAVES ETHANOLIC \\ EXTRACT AS A CHEMOPREVENTIVE AGENT IN HELA \\ CERVIC CANCER CELLS THROUGH CYTOTOXIC ACTIVITY \\ AND INDUCED APOPTOSIS
}

\author{
Nur Ismiyati, Farisya Nurhaeni \\ Prodi D3 Farmasi Poltekkes Bhakti Setya Indonesia Yogyakarta \\ Email: farisyanur@yahoo.co.id
}

\begin{abstract}
ABSTRAK
Kanker leher rahim merupakan penyebab kematian wanita akibat kanker terbesar di negara-negara berkembang. Pertumbuhan sel kanker bersifat tak terbatas karena mempunyai kemampuan untuk menghindari mekanisme apoptosis sehingga penemuan agen-agen pemacu apoptosis kini terus dikembangkan. Kemangi (Ocimum sanctum L.) dilaporkan memiliki potensi penghambatan perkembangan sel kanker melalui aktivitas sitotoksik, apoptosis, dan penghambatan angiogenesis pada sel kanker paru dan payudara. Penelitian ini bertujuan untuk mengetahui efek ekstrak etanol daun kemangi terhadap aktivitas sitotoksik dan proses pemacuan apoptosis pada sel kanker leher rahim HeLa. Evaluasi viabilitas sel melalui nilai $\mathrm{IC}_{50}$ ditetapkan dengan MTT assay. Efek pemacuan apoptosis oleh ekstrak etanol daun kemangi terhadap sel kanker HeLa diamati dengan metode pengecatan DNA menggunakan etidium bromida-akridin oranye. Hasil penelitian ini menunjukkan ekstrak etanol daun kemangi memiliki potensi sebagai agen kemopreventif pada kanker leher rahim HeLa dengan $\mathrm{IC}_{50} 209 \mu \mathrm{g} / \mathrm{mL}$. Berdasarkan hasil tersebut dapat disimpulkan penghambatan pertumbuhan sel HeLa oleh ekstrak etanol daun kemangi terjadi dengan menginduksi terjadinya apoptosis.
\end{abstract}

Kata kunci : kanker leher rahim, sel HeLa, daun kemangi, sitotoksik, apoptosis 


\section{ABSTRACT}

Cervical cancer is the most common women death-caused cancer. Ocimum sanctum L. is one of natural products that had cytotoxic effect and caused cell death via apoptosis and angiogenesis in lung cancer and breast cancer cells. The aim of the study was to identify the cytotoxic activity and apoptosisi induction of Ocimum sanctum leaves ethanolic extract on HeLa cancer cells. Active contents of Ocimum sanctum L. leaves was extracted by maceration with $96 \%$ ethanol.The cytotoxicity assay of Ocimum sanctum leaves ethanolic extract were carried out by using MTT assay. Apoptosis assay was done using double staining method using Ethidium Bromide-Acridine Orange. Ocimum sanctum L. leaves ethanolic extract inhibited HeLa cell growth with the $I_{50}$ of $209 \mu \mathrm{g} / \mathrm{mL}$. Detection of apoptosis showed that extract induced apoptosis. These results suggested that Ocimum sanctum L. leaves ethanolic extract has cytotoxic activity by inducing apoptosis on HeLa cervix cancer cells.

Keywords: cervix cancer, HeLa cancer cells, Ocimum sanctum L., cytotoxic, apoptosis

\section{PENDAHULUAN}

Kanker leher rahim atau kanker serviks merupakan penyebab kematian terbesar ketiga pada wanita di dunia dan pada negara-negara berkembang (Aziz, 2006). Di negara Indonesia, kanker ini menduduki peringkat kedua penyakit kanker yang sering diderita masyarakat setelah kanker payudara (Rekam Medis RS Kanker Dharmais, 2012). Berdasarkan kondisi ini, maka pengatasan kanker dengan menghambat dan mematikan pertumbuhan sel kanker secara selektif perlu diupayakan.

Pengobatan kanker dapat dilakukan dengan pembedahan, kemoterapi, maupun dengan radiasi. Pembedahan tidak efektif untuk kanker yang telah metastasis. Pengobatan dengan metode kemoterapi dan radiasi seringkali kurang selektif. Penggunaan kemoterapi juga memiliki efek samping toksik pada jaringan normal dan menyebabkan resistensi pada sel kanker (Davis et al., 2003). Berdasarkan alasan tersebut, maka perlu dilakukan penelitian tentang pengobatan kanker yang selektif dan aman. Salah satu pengembangan agen kemopreventif 
dari bahan alam yang dapat memperlambat atau mencegah perkembangan sel kanker.

Beberapa penelitian menunjukkan bahwa kemangi memiliki aktivitas sitotoksik dan mampu menghambat pertumbuhan sel kanker. Penelitian (NangiaMakker, et.al., 2007) menunjukkan bahwa ekstrak air kemangi dapat menghambat proliferasi dan angiogenesis pada sel kanker payudara MDA-MB-435 dan MCF10A DCIS.com yang diinjeksikan pada nude mice melalui metode xenograft. Penelitian lain mengenai ekstrak etanol dari kemangi menunjukkan aktivitas sitotoksik pada sel kanker paru A549 melalui mekanisme apoptosis (Magesh et al, 2009). Kim et al (2010) juga menyatakan bahwa ekstrak etanol daun kemangi memiliki aktivitas sitotoksik dan anti metastatik pada sel kanker paru Lewis Lung Carcinoma (LLC) melalui aktivasi enzim oksidasi.

Aktivitas sitotoksik pada kemangi ini terjadi pada mekanisme apoptosis. Penemuan senyawa baru dengan target pada pemacuan apoptosis merupakan salah satu strategi untuk pengembangan agen kemopreventif dari tanaman sebagai alternatif pengobatan kanker.

Penelitian ini bertujuan untuk menjelaskan potensi sitotoksik ekstrak etanol daun kemangi sebagai agen kemopreventif pada sel kanker leher rahim HeLa. Selain itu, dipelajari pengaruh ekstrak etanol daun kemangi pada induksi apoptosis sel kanker tersebut.

\section{METODE PENELITIAN}

Alat ekstraksi digunakan seperangkat alat gelas, kain kasa, kertas saring, pengaduk, corong porselin, Rotary Evaporator, alat penyaring, dan flakon. Alat uji in vitro digunakan adalah Autoclave (Hirayama), Laminar Air Flow Hood (Labconco), inkubator CO2 (Heraeus), inverted microscope (Zeiss MC 80), hemocytometer, penangas air, neraca analitik (Sartorius), mikropipet (Gilson), mikroskop cahaya, centrifuge (Sorvall), ELISA reader (SLT 240 ATC), cover slip, yellow dan blue tip, Tissue culture flask (nunclon), tabung conical (Nunclon), 96well plate (Nunc), 24-well plate (Nunc), shaker (MRK- RETAC), vortex, eppendorf steril (plasti brand), kamera digital (Canon, Japan). 

Bahan utama yaitu daun kemangi yang diperoleh dari daerah Piyungan, Bantul, larutan penyari adalah etanol $96 \%$ (Merck). Bahan uji sitotoksik dengan MTT adalah sel kanker leher rahim HeLa (Koleksi Cancer Chemoprevention Research Center, Fakultas Farmasi UGM), media penumbuh sel (media kultur), DMEM (Dulbecco's Modified Eagle Medium), Fungison 0,5\% (Gibco), Fetal Bovine Serum (FBS) 10\% (Gibco), dan penisilin-streptomisin 1\% (Gibco). Sel dipanen dari tissue culture disk dengan tripsin-EDTA 0,025\%. Pelarut sampel: DMSO (dimetil sulfoxida), larutan stopper: SDS (sodium dodesil sulfat) $10 \%$ dalam $\mathrm{HCl} 0,1 \mathrm{~N}$, larutan pencuci: PBS (phospat buffer saline).

\section{Jalannya Penelitian}

Ekstraksi Bahan

Simplisia dihaluskan, selanjutnya diremaserasi menggunakan etanol $96 \%$ sebanyak tiga kali kemudian filtratnya diuapkan menggunakan rotaevaporator. Pembuatan larutan uji dengan konsentrasi ekstrak yang digunakan adalah 5 $\mu \mathrm{g} / \mathrm{mL}, 25 \mu \mathrm{g} / \mathrm{mL}, 50 \mu \mathrm{g} / \mathrm{mL}, 100 \mu \mathrm{g} / \mathrm{mL}, 250 \mu \mathrm{g} / \mathrm{mL}, 500 \mu \mathrm{g} / \mathrm{mL}$, dan 750 $\mu \mathrm{g} / \mathrm{mL}$ dengan menggunakan pelarut DMSO.

\section{Uji Sitotoksik}

Uji sitotoksik dilakukan dengan menggunakan MTT Assay. Sel HeLa yang telah konfluen dipanen dan didistribusikan ke dalam sumuran pada 96-well plate dengan jumlah $10 \times 10^{3} \mathrm{sel} / \mathrm{sumuran}$. Sel diinkubasi selama 24 jam di dalam inkubator $\mathrm{CO}_{2}$ untuk adaptasi sehingga siap untuk perlakuan. Setelah 24 jam ditambahkan $100 \mu \mathrm{L}$ media kultur yang mengandung sampel dalam berbagai seri konsentrasi sebanyak 3 replikasi dan diinkubasi kembali selama 24 jam. Sebagai kontrol digunakan kontrol pelarut (DMSO), kontrol sel HeLa, dan kontrol media kultur DMEM. Pada kontrol pelarut, sel diberi DMSO sesuai dengan kadar yang sama dengan yang terdapat dalam sampel. Pada akhir inkubasi, media kultur yang ada dalam plate dibuang dengan cara membalikkan plate, kemudian dicuci dengan $100 \mu \mathrm{L}$ PBS untuk tiap sumuran. Selanjutnya masing- masing sumuran ditambah $100 \mu \mathrm{L}$ reagen MTT (stok $5 \mathrm{mg} / \mathrm{mL}$ ). Inkubasi dilanjutkan selama 3 jam pada 
suhu $37^{\circ} \mathrm{C}$ sampai terbentuk formazan. Sel yang hidup akan mengkonversikan MTT menjadi formazan yang berwarna biru tua/ ungu. Selanjutnya, ditambahkan pereaksi stopper untuk melarutkan kristal formazan dan sel diinkubasi semalam pada suhu kamar dan terlindung dari cahaya. Pada akhir inkubasi, plate digoyang secara horisontal dengan shaker selama 10 menit kemudian dibaca dengan ELISA reader pada panjang gelombang $595 \mathrm{~nm}$. Hasil absorbansi yang terbaca dikonversikan dalam persentase viabilitas sel.

Uji Apoptosis

Kultur sel HeLa yang telah konfluen dipanen dan didistribusikan dengan konsentrasi $5 \times 10^{4} \mathrm{sel} /$ sumuran dalam $1000 \mu \mathrm{L}$ ke dalam 24 well plate yang telah diberi cover slip. Setelah itu sel diinkubasi selama 24 jam dalam inkubator $\mathrm{CO}_{2}$ agar sel teradaptasi dan normal kembali. Selanjutnya sel diberi perlakuan $I C_{50}$ ekstrak, kontrol sel, dan kontrol pelarut DMSO lalu diinkubasi kembali selama 15 jam. Pada akhir inkubasi media kultur DMEM dicuci dengan PBS dan cover slip diangkat dari sumuran serta diletakkan di atas obyek gelas lalu ditetesi dengan pereaksi etidium bromida-akridin oranye (EtBr-AO) sebanyak $10 \mu \mathrm{L}$. Pengamatan morfologi sel dilakukan dengan mikroskop fluoresensi.

\section{Analisis Data}

Ekstraksi

Ekstrak etanol daun kemangi yang diperoleh dibandingkan dengan berat serbuk simplisia kering, sehingga data yang didapat adalah berupa rendemen (persamaan 1).

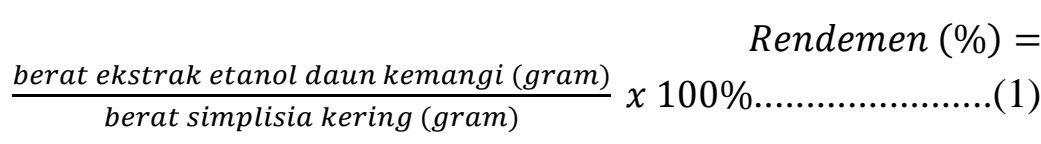

\section{Uji Sitotoksik}

Data absorbansi yang diperoleh dikonversi menjadi persen kehidupan sel dengan membandingkan jumlah sel hidup antara perlakuan dan kontrol. 
Persen kehidupan sel dihitung dengan menggunakan persamaan (2):

$\%$ sel hidup $=\frac{\text { Absorbansi sel dengan perlakuan-absorbansi kontrol media }}{\text { Absorbansi kontrol sel-absorbansi kontrol media }} \times 100 \%$

$I C_{50}$ dihitung dari hubungan linearitas antara logaritma konsentrasi larutan uji versus persen kehidupan sel. $I C_{50}$ merupakan kadar yang dapat menghambat proliferasi sel sebesar 50\% populasi sel (Doyle and Griffiths, 2000).

Pengamatan Apoptosis

Pengamatan apoptosis dilakukan secara kualitatif dengan mengamati morfologi sel HeLa di bawah mikroskop fluoresensi. Sel hidup akan tampak normal, utuh seperti aslinya, dan berfluoresensi hijau, sedangkan sel yang apoptosis awal akan tampak kondensasi, berfluoresensi hijau, sel dengan apoptosis akhir akan tampak kondensasi, terpecah-pecah, berfluoresensi merah, dan sel yang nekrosis akan tampak normal, berfluoresensi oranye sampai merah (Ribble et al., 2005).

\section{HASIL DAN PEMBAHASAN}

Pembuatan ekstrak etanol daun kemangi didapatkan hasil rendemen sebesar 9,36\%. Uji sitotoksisitas dilakukan bertujuan untuk konfirmasi kemampuan sitotoksik larutan uji terhadap sel HeLa. Uji sitotoksik dilakukan dengan metode kolorimetrik menggunakan reagen MTT \{(3-(4,5-dimetiltiazol-2-il)-2,5-difenil tetrazolium bromid\}. Uji sitotoksik memberikan gambaran potensi senyawa uji dalam menghambat pertumbuhan sel uji. Parameter yang digunakan adalah inhibition concentration $50 \%\left(I C_{50}\right)$. Konsentrasi ekstrak etanol daun kemangi yang digunakan dalam perlakuan terhadap sel HeLa adalah $5 \mu \mathrm{g} / \mathrm{mL}, 25 \mu \mathrm{g} / \mathrm{mL}$, $50 \mu \mathrm{g} / \mathrm{mL}, 100 \mu \mathrm{g} / \mathrm{mL}, 250 \mu \mathrm{g} / \mathrm{mL}, 500 \mu \mathrm{g} / \mathrm{mL}$, dan $750 \mu \mathrm{g} / \mathrm{mL}$. Hasil yang diperoleh menunjukan viabilitas sel HeLa semakin menurun seiring berdasarkan meningkatnya konsentrasi ekstrak etanol daun kemangi (Gambar 1). Berdasarkan 

perhitungan dengan menggunakan analisis probit diperoleh hasil bahwa pada sel HeLa, ekstrak etanol daun kemangi memiliki nilai $I C_{50}$ sebesar $209 \mu \mathrm{g} / \mathrm{mL}$.

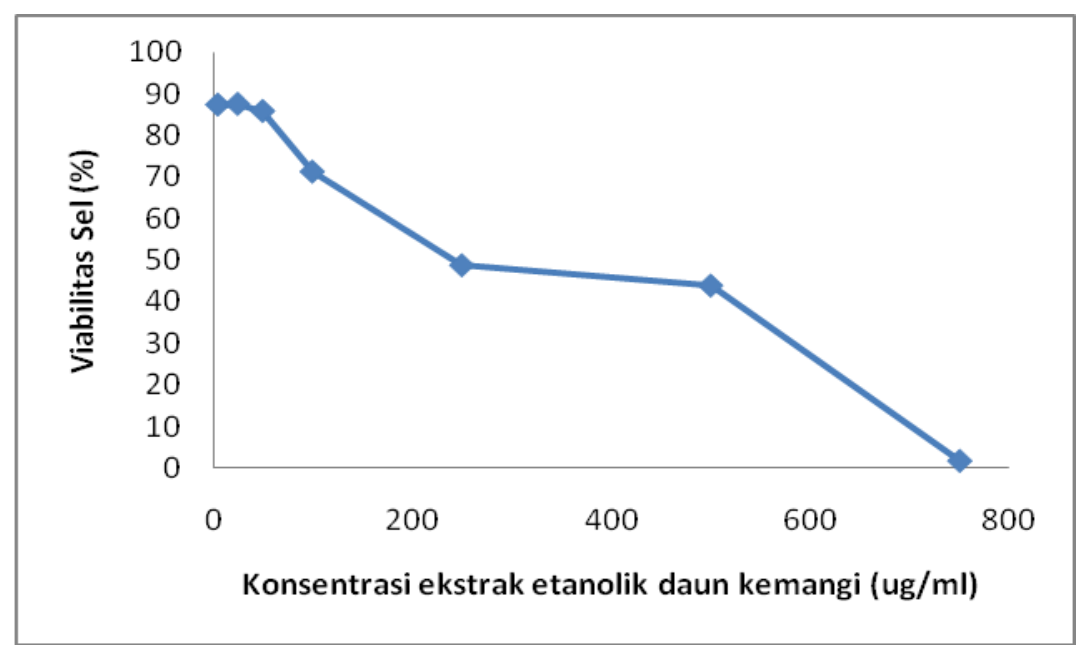

Gambar 1. Sitotoksisitas ekstrak etanol daun kemangi terhadap sel HeLa

Gambaran morfologi sel HeLa akibat perlakuan ekstrak etanol daun kemangi memberikan perubahan jika dibandingkan dengan sel tanpa perlakuan (sel kontrol). Sel HeLa normal berbentuk lonjong dan melekat pada dasar sumuran. Perlakuan senyawa uji memberikan perubahan gambaran morfologi sel HeLa berupa sel yang bentuknya bulat dan mengapung (Gambar 2). Perubahan gambaran morfologi tersebut menunjukkan bahwa sel HeLa mengalami kematian. Perubahan gambaran morfologi pada sel HeLa tersebut mendukung data hasil uji sitotoksik yang telah dilakukan yaitu jumlah sel yang hidup semakin berkurang seiring dengan bertambahnya konsentrasi estrak etanol kemangi. 

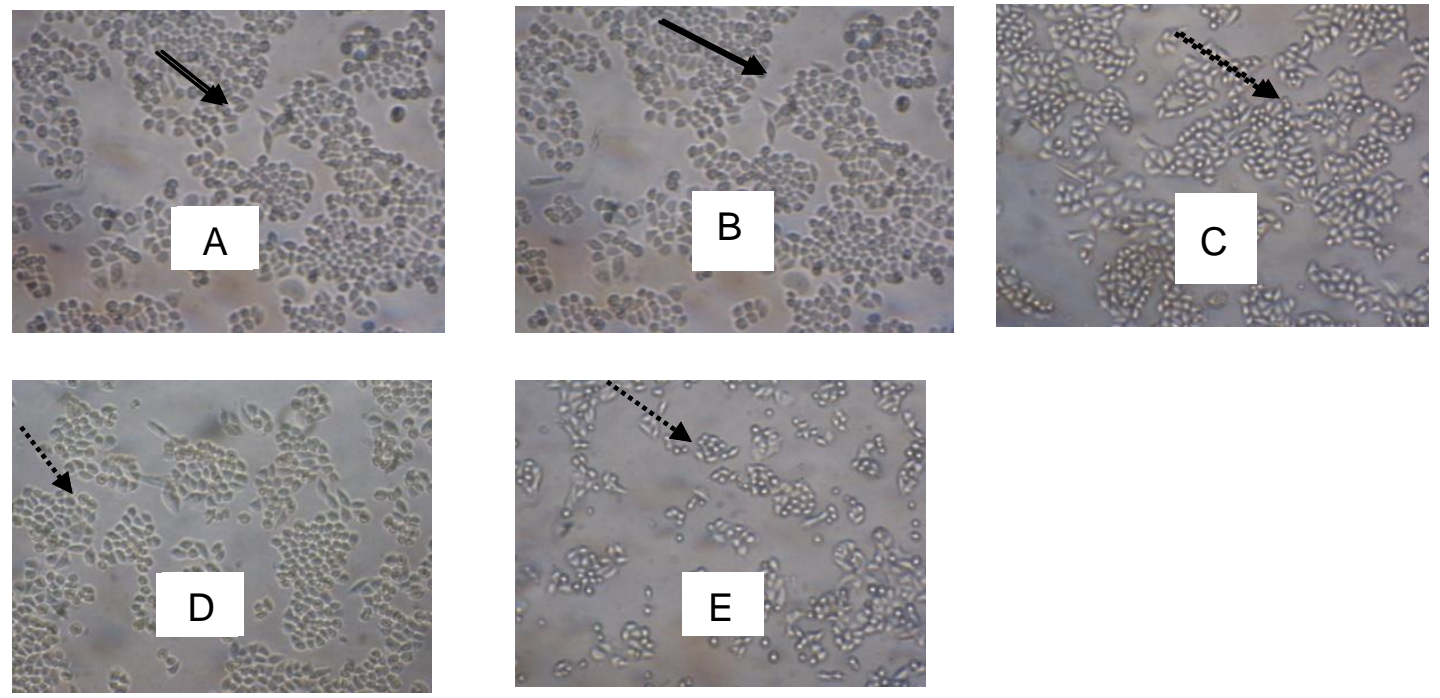

Gambar 2. Morfologi sel HeLa pada perlakuan ekstrak etanol daun kemangi. Kelompok kontrol sel (A), konsentrasi $5 \mu \mathrm{g} / \mathrm{mL}$ (B), konsentrasi $50 \mu \mathrm{g} / \mathrm{mL}$ (C), konsentrasi $100 \mu \mathrm{g} / \mathrm{mL}$ (D), dan konsentrasi $500 \mu \mathrm{g} / \mathrm{mL}$ (E). Perlakuan senyawa uji mampu menurunkan viabilitas sel berbanding lurus dengan kenaikan konsentrasi ekstrak etanol daun kemangi.

Tanda $(\longrightarrow$ menunjukkan morfologi sel normal, tanda $(\ldots \ldots \ldots)$ menunjukkan morfologi sel yang mengalami kematian.

Aktivitas senyawa uji ekstrak etanol daun kemangi untuk menghambat pertumbuhan sel HeLa atau kemampuannya untuk menyebabkan kematian sel, kemungkinan jalur dan mekanismenya bisa berbeda. Oleh karena itu, proses selanjutnya dilakukan analisis pengamatan apoptosis untuk mengetahui mekanisme penghambatan pertumbuhan tersebut. Kedua uji tersebut dilakukan dengan konsentrasi larutan uji berada di sekitar harga $I C_{50}$ yang diperoleh.

Pertama dilakukan uji apoptosis. Pengamatan gambaran morfologi sel dilakukan untuk mengetahui terjadinya kematian sel berupa apoptosis atau nekrosis pada sel HeLa akibat perlakuan suatu senyawa. Pengamatan apoptosis yang terjadi dilakukan dengan pengecatan DNA menggunakan metode double staining, yaitu pengecatan dengan menggunakan akridin oranye dan etidium bromida. Deteksi kematian sel dilakukan dengan menggunakan mikroskop fluoresen. 


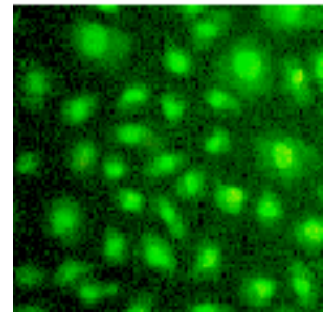

(a)

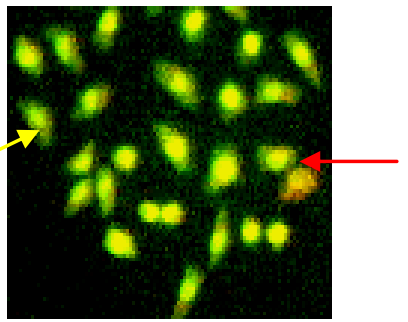

(b)

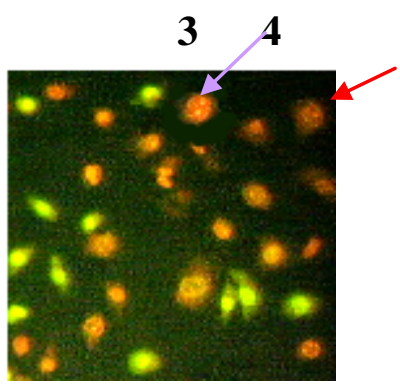

(c)

Gambar 3. Morfologi sel HeLa setelah pengecatan dengan menggunakan double staining akridin oranye-etidium bromida. Pengamatan di bawah mikroskop fluoresens, sel hidup akan tampak berbentuk daun atau bulatan dengan warna hijau yang seragam (1). Sel yang mengalami early apoptosis sel berwarna hijau dengan inti atau bagian tengah berwarna oranye (2). Sel apoptosis memiliki bentuk yang tidak teratur dengan warna oranye yang tidak seragam (3). Sedangkan sel nekrosis berwarna oranye yang seragam (4).Pengamatan dilakukan terhadap (a) kontrol sel yang berwarna hijau terang, (b) sel dengan perlakuan konsentrasi $150 \mu \mathrm{g} / \mathrm{mL}$ mulai tampak sel mengalami early apoptosis, (c) sel dengan perlakuan konsentrasi $250 \mu \mathrm{g} / \mathrm{mL}$ menunjukkan sel mengalami apoptosis dan nekrosis. Pengamatan dilakukan dengan perbesaran 40x.

Hasil pengamatan gambaran morfologi DNA dengan mikroskop fluoresen menunjukkan pada kontrol sel keseluruhan terdapat sel berwarna hijau terang yang menunjukkan sel yang masih hidup. Pada sel yang masih hidup, sel terlihat warna terang karena adanya cairan sitoplasma yang bersifat meneruskan cahaya dari mikroskop fluoresen (McGahon et al., 1995). Sedangkan pada perlakuan senyawa uji $150 \mu \mathrm{g} / \mathrm{mL}$, terlihat sel berwarna hijau dan sebagian sel berwarna hijau dengan inti atau bagian tengah berwarna oranye (Gambar 3). Keadaan tersebut merupakan tanda-tanda terjadinya early apoptosis (McGahon et al., 1995). Sel yang mengalami early apoptosis pada pengecatan double staining ini kurang jelas teramati.

Perlakuan senyawa uji $250 \mu \mathrm{g} / \mathrm{mL}$, telihat beberapa sel berwarna hijau namun sebagian besar sel berwarna oranye. Sel yang berwarna oranye terdiri dari sel yang mengalami apoptosis dan nekrosis. Sel yang mengalami apoptosis berwarna oranye dengan badan-badan apoptosis yang tidak beraturan sebagai ciri khas sel yang mengalami kematian dengan apoptosis (late apoptotic cells). Sedangkan pada sel yang berwarna oranye pada seluruh bagian sel dan sel tampak 

utuh menunjukkan terjadinya nekrosis. Pengamatan gambaran morfologi DNA yang dilakukan, dapat diketahui bahwa ekstrak etanol daun kemangi dapat memacu terjadinya kematian secara apoptosis pada sel HeLa.

Uji sitotoksik ekstrak etanol daun kemangi dilakukan dengan menggunakan metode kolorimetrik yang berdasarkan pada kemampuan enzim dehidrogenase mitokondria untuk mengkonversi MTT \{(3-(4,5-dimetiltiazol-2-il)-2,5-difenil tetrazolium bromid\}, suatu substrat berwarna kuning yang tidak larut dalam air, menjadi formazan yang berwarna biru gelap yang juga tidak larut dalam air dan melekat pada sel (Doyle and Griffiths, 2000). Formazan yang terbentuk proporsional dengan jumlah sel hidup (Mosmann, 1983). Metode ini cepat, sensitif, akurat serta dapat digunakan untuk menguji sampel dalam jumlah besar secara otomatis menggunakan spektrofotometer (Doyle and Griffiths, 2000). Metode ini juga terbukti lebih terpercaya dibandingkan dengan perhitungan sel menggunakan hemositometer.

Reaksi reduksi MTT menjadi formazan hanya dapat dilakukan oleh sel hidup. Oleh karena itu, absorbansi dari formazan yang terbentuk berbanding lurus terhadap viabilitas populasi sel (Mossman, 1983). Kemampuan enzimatik ini diperkirakan berbeda pada tiap sel yang masih hidup. Kemungkinan terdapat sel yang masih normal, tapi juga terdapat sel yang terkena efek toksik dan belum mati karena kemampuan enzimatisnya akan menurun. Pertimbangan itulah yang kemudian mendasari pengkonversian data absorbansi menjadi persen kehidupan sel, bukan sebagai persen kematian sel.

Uji sitotoksik memberikan gambaran potensi senyawa uji dalam menghambat pertumbuhan sel uji dengan parameter inhibition concentration $50 \%$ $\left(I C_{50}\right)$. Hasil uji memperlihatkan bahwa ekstrak etanol daun kemangi memiliki aktivitas sitotoksik terhadap sel HeLa yang tergantung dosis (dose dependent). Semakin meningkat konsentrasi ekstrak etanol daun kemangi yang diberikan, semakin rendah persen viabilitas sel (Gambar 1). Nilai $I C_{50}$ ekstrak etanol daun kemangi terhadap sel HeLa setelah dianalisis dengan probit diperoleh sebesar 209 $\mu \mathrm{g} / \mathrm{mL}$. 
Aktivitas sitotoksik ekstrak etanol daun kemangi terhadap pertumbuhan sel HeLa yang bersifat dose dependent juga dapat teramati pada hasil gambaran morfologi sel yang diperoleh. Gambaran morfologi sel HeLa akibat perlakuan ekstrak etanol daun kemangi memberikan perubahan terhadap sel tanpa perlakuan (sel kontrol). Konsentrasi ekstrak etanol kemangi yang semakin besar menunjukkan gambaran morfologi sel HeLa yang mengalami kematian juga semakin besar (Gambar 2). Penyebab kematian sel HeLa tersebut kemungkinan melalui mekanisme apoptosis, sehingga perlu dilakukan pengamatan.

Pengamatan apoptosis dilakukan secara kualitatif dengan mengamati gambaran morfologi sel HeLa di bawah mikroskop fluoresensi. Hasil yang diperoleh menunjukkan pada konsentrasi di bawah nilai $I C_{50}$ yaitu $150 \mu \mathrm{g} / \mathrm{mL}$ menunjukkan masih banyak sel yang hidup, namun beberapa sel sudah mengalami early apoptosis ditandai dengan sel yang berwarna hijau dengan inti atau bagian tengah berwarna oranye. Hasil tersebut sesuai dengan uji sitotoksik dimana sekitar konsentrasi $150 \mu \mathrm{g} / \mathrm{mL}$, ditemukan banyak sel yang belum mengalami kematian. Sedangkan pada konsentrasi di atas nilai $I C_{50}$ yaitu 250 $\mu \mathrm{g} / \mathrm{mL}$ menunjukkan banyak sel yang mulai mengalami late apoptotic dan nekrosis (Gambar 3). Pengamatan gambaran morfologi DNA yang dilakukan dapat diketahui bahwa ekstrak etanol daun kemangi memiliki aktivitas sitotoksik terhadap sel HeLa dengan melalui induksi jalur apoptosis.

Sel HeLa diketahui mengekspresikan 2 onkogen, yaitu E6 dan E7. E6 berikatan dengan p53 yang terfosforilasi sedangkan E7 berikatan dengan protein pRb. Protein p53 adalah suatu faktor transkripsi yang mengaktivasi transkripsi bermacam-macam gen misalnya p21. Protein p53 bertanggung jawab dalam menghentikan siklus sel sel ketika terjadi kerusakan DNA. Jika kerusakan DNA tersebut tidak dapat diperbaiki, p53 akan menginduksi apoptosis dengan mengaktivasi protein-protein pro apoptosis. Pengamatan pada sel HeLa, p53 menjadi inaktif karena terikat pada protein E6. Ikatan E7 dengan pRb akan menyebabkan $\mathrm{pRb}$ terfosforilasi dan mengakibatkan lepasnya E2F yang menginduksi gen-gen esensial untuk proses sintesis dan mitosis, akibatnya sel mamasuki proses cell cycle (DeFillippis et al., 2003). 
Daun kemangi mengandung flavonoid, terpen, dan minyak atsiri. Salah satu flavonoid polimetoksi yaitu tangeretin mampu menginduksi ekspresi protein p53 (Pan et al, 2002). Peningkatan ekspresi p53 ini akan meningkatkan level p21 dan p27 yang merupakan suatu inhibitor Cdk, khususnya Cdk2 dan Cdk4. Terhambatnya aktivitas $\mathrm{Cdk} 2$ dan Cdk4 menyebabkan $\mathrm{G}_{1}$ arrest pada daur sel (Pan et al., 2002). Aktivitas sitotoksik ekstrak etanol kemangi terhadap sel HeLa kemungkinan melalui mekanisme ini. Jadi, kemungkinan kandungan flavonoid ekstrak etanol daun kemangi dapat melepas ikatan antara E6 dan p53 sehingga p53 aktif sehingga terjadi penghambatan siklus sel yang dilanjutkan dengan apoptosis.

Enzim topoisomerase adalah enzim yang dapat mengkatalisis pemutaran dan relaksasi dari rantai DNA, dengan memotong sementara rantai DNA superhelik. Topoisomerase I memotong satu rantai sedangkan topoisomerase II memotong kedua rantai. Inhibitor topoisomerase menstabilkan kompleks topoisomerase-DNA terpotong, sehingga menghasilkan kerusakan DNA double stranded yang permanen (Beck et al., 2001). Hal ini akan menyebabkan kerusakan DNA, sehingga menginduksi ekspresi p53 dan meng-upregulasi protein p53-dependent (seperti Bax, p21, Gadd45) yang merupakan tahap awal terjadinya apoptosis. Ptaquiloside adalah suatu terpenoid yang diketahui dapat menghambat enzim topoisomerase I (Nishizawa et al., 2001). Kemungkinan senyawa tersebut bertanggung jawab atas aktivitas apoptosis melalui penghambatan aktivitas enzim topoisomerase.

Kemungkinan mekanisme apoptosis tersebut masih perlu dibuktikan melalui penelitian-penelitian selanjutnya. Senyawa yang secara pasti bertanggung jawab atas mekanisme tersebut juga masih perlu diteliti lebih lanjut untuk mendapatkan dasar ilmiah yang jelas dalam pengembangan senyawa aktif dalam daun kemangi sebagai agen kemopreventif. 


\section{KESIMPULAN}

Berdasarkan hasil penelitian yang telah dilakukan, dapat disimpulkan bahwa ekstrak etanol daun kemangi memiliki potensi sebagai agen kemopreventif melalui aktivitas sitotoksik dan induksi apoptosis terhadap sel kanker leher rahim HeLa.

\section{UCAPAN TERIMA KASIH}

Terima kasih diucapkan kepada DIPA Ditlitabmas Dirjen Dikti yang telah membiayai penelitian ini, Poltekkes Bhakti Setya Indonesia dan Cancer Chemoprevention Research Center Fakultas Farmasi UGM, Yogyakarta yang telah membantu bahan dan sarana penelitian.

\section{DAFTAR PUSTAKA}

Aziz, MF., Andrijono, Saifuddin AB, editors., 2006. Buku Acuan Nasional Onkologi Ginekologi. Edisi kedua. Jakarta: Yayasan Bina Pustaka Sarwono Prawirohardjo

Beck, W.T., Mo, Y.Y., Bhat, U.G., 2001, Cytotoxic Signaling by Inhibitor of DNA Topoisomerase II, Biochemical Society Transactions, 29 (6)

Davis, J.M., Navolonic, P.M., Weinstein, C.R., Steelman, L.S., Hu, Konovlepa, M., Blagosklonny M.V and McCubrey, J.A., 2003, Raf-1 and Bcl-2 Induce Distinct dan Commn Pathway That Contribute to Cancer Drug Resistance, Clinical Cancer Research, 9, 1161-1170.

DeFillippis, R.A., Goodwin, E.C., Wu, L., and DiMaio, D., 2003, Endogenous Human Papillomavirus E6 and E7 Proteins Differentially Regulate Proliferation, Senescence, and Apoptosis in Hela Cervical Carcinoma Cells, Journal of Virology,.77 (2) : 1551-1563.

Doyle, A., and Griffiths, J.B., 2000, Cell and Tissue Culture for Medical Research, John Willey and Sons Ltd, New York.

Kim, S.C., Magesh, V., Jeong, S.J., Ahn, K.S., Lee, H.J., Lee, E.O., Kim, S.H., Lee, M.H., Kim, J.H., 2010, Ethanol Extract of Ocimum sanctum Exerts Anti-metastatic Activity Through Inactivation of Matrix Metalloproteinase-9 and Enhancement of Anti-oxidant Enzymes, Food Chem Toxicol 48(6):1478-1482. 
Magesh, V., Lee, J.C., Ahn, K.S., Lee, H.J., Lee, H.J., Lee, E.O., Shim, B.S., Jung, H.J., Kim, J.S., Kim, D.K., Choi, S.H., Ahn, K.S., Kim, S.H., 2009, Ocimum sanctum Induces Apoptosis in A549 Lung Cancer Cells and Suppresses the In Vivo Growth of Lewis Lung Carcinoma Cells, Phytother Res 23(10): 1385-1391.

McGahon, A.J., Martin, S.J., Bissonnette, R.P., Mahboubi, M., Shi, Y., Mogil, R. J., Nishioka, W. K., and Green, D. R., 1995, The End of the (Cell) Line: Methods for the Study of Apoptosis in Vitro, in: Schwartz, L. M., Osborn, B. A., Cell Death, Academic Press, San Diego.

Mosmann, T.R. 1983. Rapid colorimetric for cellular growth and survival: application to proliferation and cytotoxic assays. J. Immunol. Methods 65:55-58.

Nangia-Makker, P., et.al., 2007, Inhibition of breast tumor growth and angiogenesis by a medicinal herb: Ocimum sanctum, Int J Cancer. August 15; 121(4): 884-894. doi:10.1002/ijc.22733.

Nishizawa, M., Yasui, Y., Ito, M., Hirono, I., and Andoh, T., 2001, New Topoisomerase I Inhibitors, TAN-1518A and Ptaquiloside: Their Mode of Action, Laboratory of Biochemistry.

Pan, M.H., Chen, W.J., Lin-Shiau, S., Ho, C.H., and Lin, J.K., 2002, Tangeretin Induces Cell-Cycle Through Inhibiting Cyclin-Dependent Kinase $2 \& 4$ Activities As Well As Elevating Cdk Inhibitor p21 in Human Colorectal Carcinoma Cells, Carcinogenesis, Oxford University Press, 23: 16771684.

Rekam Medis RS Kanker Dharmais, 2012, Statistik Kanker : 10 Besar Kanker Tersering RSKD Rawat Jalan tahun 2007, diambil dari http://www. dharmais.co.id/index.php/cancer-statistic.htmL, diakses pada bulan Maret 2012.

Ribble, D., Goldstein, N.B., Norris, D.A., and Shellman, Y.G., 2005, A Simple Technique for Quantifying Apoptosis in 96-Well Plates, BMC Biotechnology, 5:12. 